\title{
Double outlet right ventricle: a case report
}

\section{Olva Uravić Bursać*, Vesna Pehar Pejčinović, \\ DViktor Peršić, Ivana Butković}

Clinic for treatment, rehabilitation and prevention of cardiovascular disease, Thalassotherapia Opatija, Croatia
RECEIVED:

February 28, 2019

ACCEPTED:

March 24, 2019

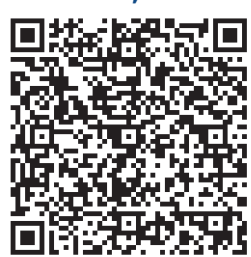

KEYWORDS: double outlet right ventricle, congenital heart disease, cardiovascular MR imaging. CITATION: Cardiol Croat. 2019;14(3-4):71. | https://doi.org/10.15836/ccar2019.71

*ADDRESS FOR CORRESPONDENCE: Iva Uravić Bursać, Thalassotherapia Opatija, M. Tita 188, HR-51410 Opatija, Croatia. / Phone: +385-91-5358-076 / E-mail: iva.uravic-bursac@tto.hr

ORCID: Iva Uravić Bursać, https://orcid.org/0000-0002-1050-0135 • Vesna Pehar Pejčinović, https://orcid.org/0000-002-8921-7999 Viktor Peršić, https://orcid.org/0000-0003-4473-5431

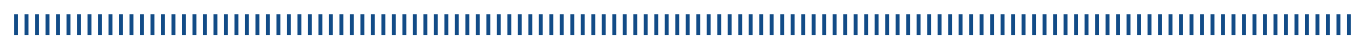

Introduction: Double outlet right ventricle (DORV) is congenital cardiac malformation which occurs $1-3 \%$ of individuals with congenital heart defects ${ }^{1}$. The echocardiography is a method of choice to detect the regional acceleration of flow and in most cases is sufficient for diagnosis and surgical planning ${ }^{1}$. When the findings at the imaging examination are inconclusive, cardiovascular MR imaging may play an important role in anatomy of the ventricular septal defect, functional status of both ventricles, and to identify any residual stenosis or regurgitation or coexistent anomalies ${ }^{2}$. In DORV both great arteries come from the same pumping chamber ${ }^{2}$. These patients require long-term follow up and may present for surgical or catheter-based interventions ${ }^{3}$. Possible complications may include heart failure, high blood pressure in the lungs or death ${ }^{3}$.

Case report: We report 43-year-old men with Blalock-Taussig shunt. He visited hospital for cardiac evaluation after he had respiratory infection with shortness of breath and palpitation. Electrocardiography showed right axis deviation and right ventricular hypertrophy. Laboratory examination revealed polycythemia and hypoxemia. This patient has associated ventricular and atrial septal defect and hypoplastic pulmonary artery. The heart showed dilatation of the bilateral ventricles, right ventricular hypertrophy with reduced systolic function (39\%). Above the right ventricle is left atrium with pulmonic veins.

Conclusion: MR imaging provides accurate additional anatomic information in patients with DORV, which is helpful in presurgical planning as well as during follow up.

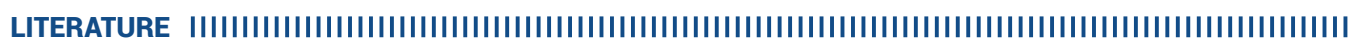

1. Pang KJ, Meng H, Hu SS, Wang H, Hsi D, Hua ZD, et al. Echocardiographic Classification and Surgical Approaches to Double-Outlet Right Ventricle for Great Arteries Arising Almost Exclusively from the Right Ventricle. Tex Heart Inst J. 2017 Aug 1;44(4):245-251. https://doi.org/10.14503/THIJ-16-5759

2. Saremi F, Ho SY, Cabrera JA, Sánchez-Quintana D. Right ventricular outflow tract imaging with CT and MRI: Part 1, Morphology. AJR Am J Roentgenol. 2013 Jan;200(1):W39-50. https://doi.org/10.2214/AJR.12.9333

3. Brown JW, Ruzmetov M, Okada Y, Vijay P. Turrentine MW. Surgical results in patients with double outlet right ventricle: a 20-year experience. Ann Thorac Surg. 2001 Nov;72(5):1630-5. https://doi.org/10.1016/S0003-4975(01)03079-X 